Wahyudin, A. · B.N. Fitriatin $\cdot$ F.Y. Wicaksono $\cdot$ Ruminta $\cdot$ A. Rahadiyan

\title{
Respons tanaman jagung (Zea mays L.) akibat pemberian pupuk fosfat dan waktu aplikasi pupuk hayati mikroba pelarut fosfat pada Ultisols Jatinangor
}

\section{Response of maize (Zea mays L.) due to application of phosphate fertilizers and application time of phosphate solubizing microbes at Ultisols Jatinangor}

Diterima : 15 Februari 2017/Disetujui : 15 Maret 2017 / Dipublikasikan : 30 Maret 2017

CDepartment of Crop Science, Padjadjaran University

\begin{abstract}
Maize is one of the food crops that has strategic role in the development of agriculture and economy in Indonesia because it has the need for food, feed, industrial raw materials, and handicrafts. The objective of this research was to determine the effects of phosphate fertilizer types and time application of phosphate solubizing microbes (PSM) on maize. The research was conducted from May to August 2014 in Ciparanje Experimental Field, Faculty of Agriculture, Universitas Padjadjaran, Jatinangor, Sumedang, West Java with altitude about 750 meters above sea level, the order soil is Ultisol, rainfall type was C3 based on Oldeman classification, and the air temperature ranged between 22,00 - 23,66 C. The experiment methods used Randomized Block Design (RBD) that consisted of 9 treatments with 3 replications. The treatments were: control (without phosphate fertilizer and PSM biofertilizer); $100 \%$ dosage of SP-36 fertilizer and rock phosphate for each of them without PSM biofertilizer; 50\% dosage of SP-36 fertilizer and rock phosphate for each of them with once application of PSM biofertilizer at before planting, twice application of PSM biofertilizer at before planting and 4 weeks after planting, and three times application of PSM biofertilizer at before planting, 3 weeks after planting and 6 weeks after planting. The results showed that the treatment of phosphate fertilizer type and time application of PSM influence on length of ears. Treatment 50\% dosage of SP-36 fertilizer with once application

\footnotetext{
Dikomunikasikan oleh Aep Wawan Irwan

Wahyudin, A. . 1, B.N. Fitriatin ${ }^{1}$, F.Y. Wicaksono',

Ruminta $^{1}$, A. Rahadiyan ${ }^{2}$

${ }^{1}$ Staf Pengajar Prodi Agroteknologi, Fak. Pertanian, Unpad

2 Alumni Prodi Agroteknologi, Fak. Pertanian, Unpad

Korespondensi: agus.wahyudin@unpad.ac.id
}

of PSM biofertilizer before planting have proven tend to gave better effect and more efficient on yield of maize.

Keywords : Maize - Phosphate fertilizers • Phosphate solubilizing microbes

Sari Jagung merupakan salah satu komoditas tanaman pangan yang mempunyai peranan strategis dalam pembangunan pertanian dan perekonomian Indonesia karena memiliki potensi dalam kebutuhan pangan, pakan, bahan baku industri, dan kerajinan tangan. Penelitian ini bertujuan untuk mengetahui pengaruh jenis pupuk fosfat dan waktu pengaplikasian pupuk hayati mikroba pelarut fosfat (MPF) terhadap pertumbuhan dan hasil tanaman jagung pada Ultisols Jatinangor. Percobaan dilaksanakan di Kebun Percobaan Ciparanje Fakultas Pertanian Universitas Padjadjaran, Jatinangor, Kabupaten Sumedang, Jawa Barat dengan ketinggian tempat \pm 750 meter di atas permukaan laut dan ordo tanah Ultisol, curah hujan rata-rata termasuk tipe C3 menurut Oldeman, dan temperatur udara berkisar antara 22,00 - 23,66 C. Percobaan dilakukan dari bulan Mei sampai Agustus 2014. Metode percobaan yang digunakan adalah Rancangan Acak Kelompok yang terdiri dari 9 perlakuan dan diulang tiga kali. Perlakuan yang diujicoba adalah sebagai berikut: control (tanpa pupuk $\mathrm{P}$ dan pupuk hayati MPF); pupuk SP-36 dan batuan fosfat masing-masig dengan dosis anjuran $100 \%$ tanpa pengaplikasian pupuk hayati; pupuk SP-36 dan batuan fosfat masing-masing dengan dosis 50\% dari anjuran dan dikombinasikan dengan pemberian pupuk hayati MPF sebanyak 1 kali pada saat sebelum tanam, 2 kali pada saat sebelum tanam dan 4 minggu setelah 
tanam (MST), dan 3 kali pada saat sebelum tanam, waktu pengaplikasian pupuk hayati mikroba pelarut fosfat memberikan pengaruh terhadap panjang tongkol. Perlakuan jenis pupuk SP-36 dengan dosis 50\% dari anjran dan waktu pengalikasian pupuk hayati MPF sebanyak 1 kali pada waktu sebelum tanam terbukti memberikan pengaruh yang cenderung lebih baik dan efisien terhadap hasil dari tanaman jagung.

Kata kunci : Jagung - Pupuk fosfat - Mikroba pelarut fosfat

\section{Pendahuluan}

Komoditas yang memiliki peranan penting di bidang pangan dan pakan adalah jagung. Usaha peningkatan produksi jagung dapat dilakukan dengan program intensifikasi berupa pemupukan yang efektif dan efisien. Pemupukan yang efektif dan efisien sangat penting dilakukan di tanah yang marginal. Salah satu tanah marginal di Indonesia yaitu tanah Ultisols.

Ultisols merupakan salah satu ordo tanah di Indonesia yang mempunyai sebaran luas mencapai 45.794 .000 ha atau sekitar 25\% dari total luas daratan Indonesia (Subagyo dkk., 2004) dan sebagian besar budidaya tanaman pangan banyak dilakukan pada ordo Ultisols seperti jagung. Tanah ini memiliki kendala dalam pemanfaatannya antara lain yaitu mempunayi sifat fisik, kimia dan biologi kurang mendukung pertumbuhan tanaman. Nilai $\mathrm{pH}$ yang biasanya masam, serta kandungan unsure hara terutama $\mathrm{P}$ yang rendah karena adanya fiksasi P merupakan kendala bagi pertumbuhan tanaman. Tanah dengan $\mathrm{pH}$ yang tinggi memiliki permasalahan rendahnya kandungan $\mathrm{P}$ tersedia tanah karena adanya fiksasi oleh kalsium tanah (Tan, 2008).

Unsur P di dalam tanah berasal dari bahan organic (pupuk kandang dan sisa tanaman), pupuk buatan, dan mineral-mineral di dalam tanah. Jenis $\mathrm{P}$ di dalam tanah yaitu $\mathrm{P}$ organic dan $\mathrm{P}$ anorganik. Tnaman menyerap $\mathrm{P}$ dalam bentuk P anorganik. Ketersediaan P anorganik dipengaruhi oleh faktor kemasaman tanah, senyawa $\mathrm{Fe}, \mathrm{Al}$, dan $\mathrm{Ca}$ yan terlarut, tingkat dekomposisi bahan organik, dan aktivitas mikroorganisme (Hardjowigeno 2007)

Menurut Buckman and Brady (1969) unsur P mempunyai peranan sangat penting bagi tanaman jagung dalam proses respirasi, pemindahan dan penggunaan energi (ATP-ADP-AMP), pembelahan sel, pertumbuhan jaringan meristem, serta pembentukan bagian-bagian generatif seperti bunga dan buah. Penambahan unsur P melalui pemupukan harus berdasarkan pertimbanganpertimbangan tertentu seperti hasil uji tanah, tanaman, jenis pupuk.

Jenis pupuk yang dapat menambah unsur $P$ dalam tanah antara lain pupuk Super Phosphate 36 (SP-36) dan Rock Phosphate (batuan fosfat). Pupuk SP-36 adalah salah satu pupuk fosfor yang biasanya digunakan untuk mengatasi masalah kekahatan unsur $\mathrm{P}$ pada tanah masam. Pupuk SP-36 memiliki sifat mudah larut di dalam air yang menyebabkan sebagian besar unsur $\mathrm{P}$ akan difiksasi oleh $\mathrm{Al}$ dan Fe pada tanah, sehingga $\mathrm{P}$ menjadi tidak tersedia bagi tanaman.

Perubahan $\mathrm{pH}$ juga memberikan pengaruh terhadap ketersediaan P dalam tanah. Menurut hasil penelitian Sholeha (2011) menunjukkan bahwa dosis batuan fosfat dari deposit yang berbeda memberikan respon yang berbeda pada tanaman jagung. Dosis $300 \mathrm{~kg} / \mathrm{ha}$ menunjukkan berbeda sangat nyata pada deposit Tuban dan dosis $300 \mathrm{~kg} / \mathrm{ha}$ pada deposit Pamekasan menunjukkan hasil paling kecil dalam menyediakan P pada 30 hst. Hal ini menunjukkan pemberian dosis dengan perlakuan $300 \mathrm{~kg} / \mathrm{ha}$ berpengaruh terhadap penyediaan $\mathrm{P}$ untuk tanaman. Perlakuan denga dosis $300 \mathrm{~kg} / \mathrm{ha}$ juga menunjukkan hasil yang lebih optimal pada tinggi tanaman, berat basah dan berat kering tanaman jagung. Serapan hara $\mathrm{P}$ yang tinggi membantu bahan pembentuk inti sel. Selain itu mempunyai peran penting bagi perkembangan jaringan meristem. Ketersediaan P yang tinggi dalam larutan tanah akibat dari pemupukan $\mathrm{P}$ memungkinkan penyerapan hara yang tinggi oleh tanaman.

Menurut Isrun (2006) hasil tanaman jagung terus meningkat seiring dengan meningkatnya dosis pupuk fosfat yang diberikan ke dalam tanah. Dosis anjuran untuk tanaman jagung adalah urea sebanyak $300 \mathrm{~kg} / \mathrm{ha}$, SP-36 sebanyak $150 \mathrm{~kg} / \mathrm{ha}$, dan KCl sebanyak $100 \mathrm{~kg} / \mathrm{ha}$.

Untuk mencapai hasil tanaman jagung yang tinggi maka diperlukan dosis pemupukan fosfat yang juga tinggi, namun residu yang ditinggalkan oleh pupuk dapat mencemari lingkungan. Penambahan unsur P dalam bentuk pupuk mudah larut juga tidak mengatasi masalah kurangnya P-tersedia di tanah Ultisols karena penambahan tersebut dihadapkan pada 
masalah adsorpsi, fiksasi dan imobilisasi. Hanya sebagian dari unsur $\mathrm{P}$ yang diadsorpsi oleh mineral sehingga dapat tersedia kembali bagi tanaman (Winarso, 2005)

Untuk meningkatkan efisiensi pemupukan dan meningkatkan pertumbuhan tanaman, maka perlu dikembangkan bioteknologi tanah, yaitu salah satu contohnya pemanfaatan mikroba yang berperan dalam tranformasi unsur hara $\mathrm{P}$ di dalam tanah yang dikenal dengan mikroba pelarut fosfat (MPF) yang terdiri dari bakteri dan fungi pelarut fosfat. Mikroba ini berperan penting dalam transformasi $\mathrm{P}$ yaitu dalam mineralisasi senyawa $\mathrm{P}$ organic dengan melepaskan $\mathrm{P}$ anorganik, mengubah kelarutan senyawa $\mathrm{P}$ anorganik, oksidasi atau reduksi senyawa $\mathrm{P}$ anorganik dan juga dalam immobilisasi P (Fitriatin dkk,2013)

Menurut Suriadikarta dan Simanungkalit (2006), selain berguna dalam transformasi unsur $\mathrm{P}$, mikroba pelarut fosfat juga menghasilkan sejumlah besar fosfat terlarut sebagai kelebihan dari pasokan nutrisinya ke dalam larutan tanah. Dengan pelarutan fosfat oleh mikroba tersebut, maka fosfat tersedia dalam tanah meningkat dan dapat diserap oleh akar tanaman. Untuk dapat mencapai akar secara alami hara fosfat yang larut masuk melalui mekanisme difusi.

Penggunaan mikroba pelarut fosfat dapat mensubstitusi sebagian atau seluruhnya kebutuhan tanaman akan pupuk fosfat, tergantung kandungan $\mathrm{P}$ di dalam tanah dan memberikan hasil yang positif terhadap pertumbuhan dan perkembangan tnaman. Inokulan bakteri pelarut fosfat memberikan hasil yang sama dengan pemberian pupuk TSP dan inokulasi bakteri pelarut fosfat dan aplikasi batuan fosfat pada tanah masam Ultisols mampu meningkatkan ketersediaan $\mathrm{P}$, serapan $\mathrm{P}$, dan bobot biji kering kacang tanah (Suriadikarta dan Simanungkalit, 2006)

Menurut Fitriatin dkk. (2013), aplikasi MPF dan pupuk $P$ tidak memberikan pengaruh yang signifikan terhadap peningkatan $\mathrm{P}$ tersedia tanah. Hal ini diduga dapat disebabkan aplikasi MPF yang hanya satu kali pada awal tahun menyebabkan kerja MPF tidak optimum sampai fase vegetatif akhir. Seperti pada penelitian Layla dkk. (2013) yang menunjukkan bahwa pupuk hayati yang diberikan 2 kali yaitu pada saat tanaman berumur 14 HST dan 35 HST dengan dosis $50 \mathrm{~kg} / \mathrm{ha}$ memberikan pengaruh terbaik pada pertumbuhan dan pertumbuhan dan produksi jagung hibrida.

\section{Bahan dan Metode}

Penelitian dilakukan di kebun percobaan Ciparanje Fakultas Pertanian Universitas Padjadjaran, Jatinangor, Kabupaten Sumedang, Jaawa Barat dengan ketinggian tempat 725 meter di atas permukaan laut dan ordo ultisols, tipe curah hujan C3 menurut Oldeman (1975). Percobaan ini dilakukan dari bulan Mei 2014 sampai dengan bulan Agustus 2014.

Bahan yang digunakan pada penelitian ini antara lain adalah benih jagung hibrida (Zea mays L.), inokulan bakteri pelarut fosfat Pseudomonas mallei dan Pseudomonas cepacea, jamur pelarut fosfat Penicillium sp. dan Aspergillus sp. Yang merupakan koleksi Laboratorium Biologi dan Bioteknologi Tanah Fakultas Pertanian Universitas Padjadjaran, carrier (kompos dan gambut dengan perbandingan 1:1), media Pikovskaya sebagai media uji populasi MPF, Nutrient Broth (NB) sebagai media perbanyakan JPF, pupuk urea, $\mathrm{KCl}$, SP-36 dan batuan fosfat, pupuk kandang sapi sebagai pupuk dasar. Alat yang digunakan pada penelitian ini antara lain adalah cangkul, tugal, alat penyiraman, tali rapia, meteran, label, plastic, jangka sorong, timbangan analitik, timbangan, oven listrik, leaf area meter, peralatan laboratorium untuk pembuatan inokulan dan alat tulis.

Metode percobaan yang digunakan adalah Rancangan Acak Kelompok (RAK), terdiri dari 9 perlakuan dan diulang tiga kali untuk tiap perlakuan, sehingga terdapat 27 petak perlakuan. Tanaman yang diambil sebagai sampel per petak merupakan $10 \%$ dari jumlah populasi keseluruhan yang diambil secara acak dari seluruh tanaman kecuali baris tanaman paling luar atau border.

Perlakuan digunakan dengan pemberian pupuk SP-36 dan pupuk batuan fosfat serta pupuk hayati MPF padat. Pupuk hayati ini diberikan 1 kali, 2 kali dan 3 kali. Adapun rancangan perlakuannya adalah sebagai berikut :

$\mathrm{A}=$ Kontrol (tanpa pupuk $\mathrm{P}$ dan pupuk hayati MPF), B = Pupuk SP-36 dosis 100\% rekomendasi $(100 \mathrm{~kg} / \mathrm{ha}), \mathrm{C}=$ Batuan fosfat dosis $100 \%$ rekomendasi (300 kg/ha), D = Pupuk SP-36 50\% dari dosis rekomendsi + pupuk hayati MPF pemberian $1 \mathrm{kali}$ (awal tanam) (50 kg/ha), E = Pupuk SP-36 50\% dari dosis rekomendasi + pupuk hayati MPF pemberian 2 kali (awal tanam dan 4 MST) (50 kg/ha), F = Pupuk SP-36 
$50 \%$ dari dosis rekomendasi + pupuk hayati MPF pemberian 3 kali (awal tanam, 3 dan 6 MST) $(50 \mathrm{~kg} / \mathrm{ha}), \mathrm{G}=$ Batuan fosfat $50 \%$ dari dosis rekomendasi + pupuk hayati MPF pemberian 1 kali (awal tanam) (50 kg/ha), $\mathrm{H}=$ Batuan fosfat $50 \%$ dari dosis rekomendasi + pupuk hayati MPF pemberian 2 kali (awal tanam dan $4 \mathrm{MST})(50 \mathrm{~kg} / \mathrm{ha})$ dan $\mathrm{I}=$ Batuan fosfat $50 \%$ dari dosis rekomendasi + pupuk hayati MPF padat pemberian 3 kali (awal tanam, 3 dan 6 MST) (50 kg/ha)

Pengamatan utama komponen pertumbuhan jagung dilakukan terhadap sampel tanaman yang diambil sekurang-kurangnya 10\% dari jumlah atau populasi tanaman setiap petak perlakuan. Data pada pengamatan utama dianalisis secara statistik. Pengamatan utama meliputi pertumbuhan tanaman, komponen hasil, dan hasil tanaman jagung, yaitu : tinggi tanaman $(\mathrm{cm})$, indeks luas daun $\left(\mathrm{cm}^{2}\right)$, panjang tongkol $(\mathrm{cm})$, diameter tongkol $(\mathrm{cm})$, jumlah biji per tongkol (cm), jumlah baris biji per tongkol (cm), bobot 100 biji kering (g), bobot biji pipilan kering pertanaman (g), bobot biji pipilan kering per petak (kg/petak), bobot biji pipilan kering per hektar (ton/ha) dan indeks panen.

\section{Hasil dan Pembahasan}

Tinggi Tanaman. Berdasarkan Tabel 1, tinggi tanaman jagung pada 4 MST, 6 MST, dan 8 MST menunjukkan pengaruh yang tidak berbeda nyata dari semua perlakuan. Meskipun semua perlakuan tidak menunjukkan pengaruh yang berbeda nyata, perlakuan batuan fosfat dengan dosis $50 \%$ yang dikombinasikan dengan pemberian pupuk hayati sebanyak 2 kali menunjukkan hasil yang cenderung lebih baik dibandingkan control dan perlakuan lain. Nilai tinggi tanaman terbesar pada percobaan ini mencapai 216,93 cm. Jika dibandingkan dengan deskripsi jagung hibrida pertiwi-2 yang bisa mencapai $294 \mathrm{~cm}$, hasil percobaan ini menunjukkan bahwa pertumbuhan belum optimal.

Hal ini dapat disebabkan oleh pertumbuhan mikroba pelarut fosfat yang belum maksimal pada saat awal percobaan. Hal ini didukung oleh hasil penelitian Husen (2009), yang menyatakan bahwa pada awal percobaan, pertumbuhan karakter fungsional inokulan dala melarutkan $\mathrm{P}$ maupun memacu pertumbuhan tanaman jagung belum bekerja secara optimal.
Tabel 1. Pengaruh Jenis Pupuk Fosfat dan Waktu Aplikasi Pupuk Hayati Mikroba Pelarut Fosfat terhadap Tinggi Tanaman Jagung pada 4 MST, 6 MST dan 8 MST (cm)

\begin{tabular}{cccc}
\hline \hline Perlakuan & 4 MST & 6 MST & 8 MST \\
\hline A & $67,53 \mathrm{a}$ & $150,47 \mathrm{a}$ & $210,73 \mathrm{a}$ \\
B & $61,87 \mathrm{a}$ & $136,67 \mathrm{a}$ & $191,00 \mathrm{a}$ \\
C & $70,53 \mathrm{a}$ & $137,53 \mathrm{a}$ & $195,67 \mathrm{a}$ \\
D & $69,20 \mathrm{a}$ & $149,67 \mathrm{a}$ & $212,07 \mathrm{a}$ \\
E & $74,80 \mathrm{a}$ & $152,53 \mathrm{a}$ & $207,73 \mathrm{a}$ \\
F & $70,20 \mathrm{a}$ & $142,33 \mathrm{a}$ & $196,93 \mathrm{a}$ \\
G & $76,00 \mathrm{a}$ & $149,00 \mathrm{a}$ & $203,80 \mathrm{a}$ \\
H & $78,00 \mathrm{a}$ & $160,67 \mathrm{a}$ & $216,93 \mathrm{a}$ \\
I & $70,33 \mathrm{a}$ & $147,20 \mathrm{a}$ & $209,13 \mathrm{a}$ \\
\hline \hline
\end{tabular}

Keterangan : Nilai rata - rata yang diikuti huruf yang sama pada kolom yang sama tidak berbeda nyata menurut uji jarak duncan pada taraf $5 \%$

Indeks Luas Daun. Indeks Luas Daun (ILD) merupakan parameter yang dapat menunjukkan potensi tanaman dalam melakukan fotosintesis. Hal ini secara langsung dapat mempengaruhi pertumbuhan dan perkembangan tanaman. Semakin luas daun pada suatu tanaman, maka semakin maksimal pula penyerapan cahayanya.

Tabel 2. Pengaruh jenis Pupuk Fosfat dan Waktu Aplikasi Pupuk Hayati Mikroba Pelarut Fosfat terhadap Indeks Luas Daun

\begin{tabular}{cc}
\hline \hline Perlakuan & Indeks Luas Daun \\
\hline A & $4.88 \mathrm{a}$ \\
B & $3.72 \mathrm{a}$ \\
C & $4.35 \mathrm{a}$ \\
D & $4.71 \mathrm{a}$ \\
E & $4.70 \mathrm{a}$ \\
F & $3.87 \mathrm{a}$ \\
G & $4.28 \mathrm{a}$ \\
H & $5.05 \mathrm{a}$ \\
I & $4.63 \mathrm{a}$ \\
\hline \hline
\end{tabular}

Keterangan : Nilai rata-rata yang diikuti huruf yang sama pada kolom yang sama tidak berbeda nyata menurut uji jarak berganda Duncan pada taraf $5 \%$.

Menurut Gardner dan Pearce (1991) kisaran indeks luas daun yang optimal bagi tanaman budidaya adalah dari nilai 3 sampai nilai 5. Berdasarkan Tabel 2, perlakuan batuan fosfat dengan dosis $50 \%$ dari anjuran dengan pengaplikasian pupuk hayati sebanyak 2 kali cenderung memberikan hasil lebih baik terhadap indeks luas daun dibandingkan dengan control dan perlakuan lain. Meski demikian, semua perlakuan tidak memberikan pengaruh nyata terhadap indeks luas daun. 
Menurut Sutopo (2003), penambahan unsur hara $\mathrm{P}$ pada tanaman jagung tidak mendorong meningkatnya pertambahan luas daun karena unsur hara $\mathrm{P}$ bukanlah fakktor pembatas indeks luas daun. Menurut Goldsworthy dan Fisher (1992), faktor yang dapat mempengaruhi besarnya indeks luas daun antara lain adalah jarak tanam dan penyediaan unsur hara nitrogen. Tidak ada perbedaan jarak tanam dan dosis pupuk penyedia unsur hara nitrogen yang digunakan oleh semua perlakuan dalam percobaan ini.

Panjang Tongkol dan Diameter Tongkol Per Tanaman. Berdasarkan deskripsi benih jagung Pertiwi-2, rata-rata panjang tongkol adalah $20 \mathrm{~cm}$. Pada percobaan ini panjang tongkol darri seluruh perlakuan memnuhi kriteria yang baik dalam hal panjang tongkol. Pada percobaan ini, panjang tongkol memiliki nilai rata-rata antara $20,31 \mathrm{~cm}$ sampai $21,47 \mathrm{~cm}$. Diameter tongkol per tanaman memiiki nilai rata-rata yang berkisar antara $4.53 \mathrm{~cm}$ sampai $5,03 \mathrm{~cm}$ dan semua perlakuan tidak memiliki pengaruh yang nyata terhadap diameter tongkol. Meski demikian, perlakuan batuan fosfat $50 \%$ dengan 2 kali waktu aplikasi pupuk hayati cenderung memberikan diameter tongkol lebih baik dibandingkan dengan control dan perlakuan lain.

Hasil panjang tongkol terendah terdapat pada perlakuan $G$, yaitu pengaplikasian pupuk batuan fosfat dengan pemberian 1 kali pupuk hayati MPF di 0 MST. Meski perlakuan C dengan pengaplikasian batuan fosfat 100\% tanpa pemberian pupuk hayati MPF memberikan nilai paling tinggi terhadap panjang tongkol, perlakuan D dengan pengaplikasian pupuk SP-36 50\% yang dikombinasikan dengan pemberian pupuk hayati 1 kali dinilai cenderung lebih efisien.

Menurut penelitian yang dilakukan oleh Hasanudin dan Bambang (2004), asam-asam organic yang dihasilkan mikroba pelarut fosfat mampu meningkatkan kelarutan P tak tersedia menjadi $\mathrm{P}$ tersedia dalam tanah, sehingga penyerapan $\mathrm{P}$ oleh tanaman juga akan semakin meningkat. Tersedianya dan terserapnya unsur $\mathrm{P}$ menyebabkan fotosintat yang dialokasikan ke tongkol menjadi lebih banyak sehingga ukuran buah menjadi lebih besar. Metabolisme tanaman juga akan lebih aktif sehingga proses pemanjangan, pembelahan dan diferensiasi sel akan lebih baik sehingga peningkatan bobot, panjang dan diameter buah akan terjadi (Budiman, 2004).
Tabel 3. Pengaruh Jenis pupuk Fosfat dan Waktu Aplikasi Pupuk Hayati Mikroba Pelarut Fosfat terhadap Panjang Tongkol dan Diameter Tongkol Per Tanaman.

\begin{tabular}{ccc}
\hline \hline Perlakuan & $\begin{array}{c}\text { Panjang } \\
\text { Tongkol }(\mathbf{c m})\end{array}$ & $\begin{array}{c}\text { Diameter } \\
\text { Tongkol }(\mathbf{c m})\end{array}$ \\
\hline $\mathrm{A}$ & $21,47 \mathrm{c}$ & $4,71 \mathrm{a}$ \\
$\mathrm{B}$ & $20,95 \mathrm{abc}$ & $4,53 \mathrm{a}$ \\
$\mathrm{C}$ & $21,53 \mathrm{c}$ & $4,65 \mathrm{a}$ \\
$\mathrm{D}$ & $21,5 \mathrm{c}$ & $4,78 \mathrm{a}$ \\
$\mathrm{E}$ & $21,36 \mathrm{c}$ & $5,01 \mathrm{a}$ \\
$\mathrm{F}$ & $20,51 \mathrm{ab}$ & $4,81 \mathrm{a}$ \\
$\mathrm{G}$ & $20,31 \mathrm{a}$ & $4,85 \mathrm{a}$ \\
$\mathrm{H}$ & $21,21 \mathrm{bc}$ & $5,03 \mathrm{a}$ \\
I & $21,07 \mathrm{abc}$ & $4,91 \mathrm{a}$ \\
\hline \hline
\end{tabular}

Keterangan : Nilai rata-rata yang diikuti huruf yang sama pada kolom yang sama tidak berbeda nyata menurut uji jarak berganda Duncan pada taraf 5\%

Jumlah Biji Per Tongkol dan Jumlah Baris Biji Per Tongkol. Tabel 4 menunjukkan seluruh perlakuan tidak memberikan pengaruh yang nyata terhadap jumlah biji per tongkol ataupun jumlah baris biji per tongkol. Namun perlakuan D dengan pengaplikasian pupuk SP-36 50\% yang dikombinasikan dengan pemberian pupuk hayati 1 kali memberikan hasil yang cenderung lebih baik dibandingkan dengan control dan perlakuan lain. Nilai jumlah baris biji per tongkol dan jumlah biji per tongkoll sangat dipengaruhi oleh besarnya serapan tanaman terhadap faktor lingkungan dan unsur $P$

Tabel 4. Pengaruh Jenis Pupuk Fosfat dan Waktu Aplikasi Pupuk Hayati Mikroba Pelarut Fosfat terhadap Jumlah biji Per Tongkol dan Jumlah Baris Biji Per Tongkol.

\begin{tabular}{ccc}
\hline \hline Perlakuan & $\begin{array}{c}\text { Jumlah Biji } \\
\text { Per Tongkol }\end{array}$ & $\begin{array}{c}\text { Jumlah Baris Biji } \\
\text { Per Tongkol }\end{array}$ \\
\hline A & $610.47 \mathrm{a}$ & $16.93 \mathrm{a}$ \\
B & $580.93 \mathrm{a}$ & $16.87 \mathrm{a}$ \\
C & $604.33 \mathrm{a}$ & $16.13 \mathrm{a}$ \\
D & $642.87 \mathrm{a}$ & $17.73 \mathrm{a}$ \\
E & $637.40 \mathrm{a}$ & $16.93 \mathrm{a}$ \\
F & $597.07 \mathrm{a}$ & $17.07 \mathrm{a}$ \\
G & $571.87 \mathrm{a}$ & $16.47 \mathrm{a}$ \\
H & $628.93 \mathrm{a}$ & $16.27 \mathrm{a}$ \\
I & $589.40 \mathrm{a}$ & $16.27 \mathrm{a}$ \\
\hline \hline
\end{tabular}

$\overline{\text { Keterangan : Nilai rata-rata yang diikuti huruf yang }}$ sama pada kolom yang sama tidak berbeda nyata menurut uji jarak berganda Duncan pada tahap 5\%

Berdasarkan deskripsi jagung hibrida Pertiwi-2, jumlah baris biji adalah $14+16$ baris 
per tongkol. Banyaknya jumlah baris biji dari setiap tongkol akan mempengaruhi banyaknya jumlah biji di setiap tongkol tersebut. Pada percobaan ini, seluruh perlakuan mencapai criteria yang baik dalam jumlah baris biji per tongkol, yaitu antara 16 sampai 17 baris.

Gardner dan Pearce (1991) mengemukakan bahwa unsur $\mathrm{P}$ akan bergerak dalam tubuh tanaman dan dapat diredibustrasi dari bagian tua ke bagian yang lebih muda. Pada saat tanaan memasuki fase pengisian biji, cadangan karbohidrat diubah menjadi gula dan ditranslokasi ke biji yang sedang berkembang.

Bobot 100 Biji Kering. Bobot 100 biji kering secara tidak langsung dapat mempengaruhi hasil tanaman berupa bobot pipilan kering. Bobot 100 biji merupakan parameter yang menunjukkan besar endosperm pada biji. Endosperm adalah bagian terbesar dari biji yang merupakan tempat menyimpan cadangan makanan (Kusnadi, 2000).

Tabel 5. Pengaruh Jenis Pupuk Fosfat dan Waktu Aplikasi Pupuk Hayati Mikroba Pelarut Fosfat terhadap Bobot 100 Biji Kering (g)

\begin{tabular}{cc}
\hline \hline Perlakuan & Bobot 100 Biji Kering \\
\hline A & $25.31 \mathrm{a}$ \\
B & $23.08 \mathrm{a}$ \\
C & $24.54 \mathrm{a}$ \\
D & $25.61 \mathrm{a}$ \\
E & $27.15 \mathrm{a}$ \\
F & $24.35 \mathrm{a}$ \\
G & $23.96 \mathrm{a}$ \\
H & $26.27 \mathrm{a}$ \\
I & $24.99 \mathrm{a}$ \\
\hline \hline
\end{tabular}

Keterangan : Nilai rata-rata yang diikuti huruf yang sama pada kolom yang sama tidak berbeda nyata menurut uji jarak berganda Duncan pada taraf 5\%.

Berdasarkan Tabel 5, bobot 100 biji menunjukkan pengaruh yang tidak berbeda nyata dari semua perlakuan. Bobot 100 biji kering pada percobaan kali ini berkisar antara 23 sampai $27 \mathrm{~g}$. Menurut deskripsi jagung pertiwi2, kisaran bobot 100 biji kering +_ 30,9 g. Hasil ini menunjukkn bahwa perlakuan jenis pupuk fosfat dan waktu aplikasi pupuk hayati mikroba pelarut fosfat pada perlakuan manapun belum dapat memberikan hasil yang optimal dalam bobot 100 biji, meskipun jenis pupuk SP-36 dan pengaplikasian pupuk hayati MPF sebanyak 2 kali cenderung memberikan hasil yang lebih tinggi terhadap bobot 100 biji kering dibandingkan dengan kontrol dan perlakuan lain.
Hal ini mengindikasikan belum terserapnya unsur $\mathrm{P}$ secara optimal oleh tanaman jagung. Rahni (2012), mengemukakan bahwa peningkatan bobot kering biji berkaitan dengan besarnya translokasi fotosintat ke dalam biji dan semakin baiknya sistem perakaran tanaman untuk mengabsorbsi unsur hara dari dalam tanah. Translokasi fotosintat yang cukup besar ke organ-organ reproduktif menyebabkan pembentukan tongkol dan pengisian biji berlangsung dengan baik dan biji-biji yang terbentuk bernas dengan ukuran yang lebih besar.

Belum maksimalnya bobot 100 biji pada tanaman jagung juga dapat dipengaruhi oleh inokulan yang digunakan untuk pupuk hayati. Inokulan yang digunakan adalah bakteri pelarut Pseudomonas mallei dan Pseudomonas cepacea, serta jamur pelarut fosfat Penicillium sp. dan Aspergillus sp. Diduga inkulan yang digunakan ini belum dapat bekerja secara optimal. Menurut penelitian yang dilakukan Viruel et al. (2014), inokulan Pseudomonas tolaasii terbukti dapat meningkatkan pertubuhan, hasil tanaman, dan nutrisi $P$.

Bobot Biji Pipilan Kering Per Tanaman, Bobot Biji Pipilan Kering Per Petak, dan Bobot Biji Pipilan Kering Per Hektar. Dari hasil analisis ragam dengan menggunakan uji jarak berganda Duncan pada taraf nyata 5\% yang terdapat pada tabel 6 menunjukkan bahwa perlakuan pengaruh jenis pupuk fosfat dan waktu aplikasi pupuk hayati mikroba pelarut fosfat memberikan hasil tidak berbeda nyata dari semua perlakuan terhap bobot biji pipilan kering per tanaman (g), bobot pipilan kering per petak, dan bobot pipilan kering per hektar (ton/ha). Menurut deskripsi, rata-rata hasil produksi jagung Pertiwi-2 adalah 9,66 ton/ha pipilan kering, sedangkan dari hasil penelitian ini didapatkan rata-rata tertinggi pipilan kering sebesar 6,46 ton/ha.

Perlakuan SP-36 50\% dengan pemberian pupuk hayati MPF 1 kali pada waktu sebelum tanam cenderung memberikan hasil yang lebih efisien dibandingkan dengan kontrol dan perlakuan lain. Meski demikian, semua perlakuan tidak memberikan hasil yang berbeda nyata dan hasil prosuksi yang dideskripsikan. Hal ini mungkin dikarenakan setelah masa vegetatif, mikroba yang ada di pupuk hayati MPF sudah tidak bisa bertahan karena tempat hidupnya sudah tidak lagi dalam kondisi optimal. 
Tabel 6. Pengaruh Jenis Pupuk Fosfat dan Waktu Aplikasi Pupuk Hayati Mikroba Pelarut Fosfat terhadap Tinggi Tanaman Jagung pada 4 MST, 6 MST dan 8 MST (cm)

\begin{tabular}{cccc}
\hline \hline $\begin{array}{c}\text { Perla- } \\
\text { kuan }\end{array}$ & $\begin{array}{c}\text { Bobot Biji } \\
\text { Pipilan } \\
\text { Kering per } \\
\text { Tanaman (g) }\end{array}$ & $\begin{array}{c}\text { Bobot Biji } \\
\text { Pipilan } \\
\text { Kering per } \\
\text { Petak (kg) }\end{array}$ & $\begin{array}{c}\text { Bobot Biji } \\
\text { Pipilan } \\
\text { Kering per } \\
\text { Hektar } \\
\text { ton/ha }\end{array}$ \\
\hline A & $148.65 \mathrm{a}$ & $3.78 \mathrm{a}$ & 5.35 \\
B & $133.30 \mathrm{a}$ & $3.80 \mathrm{a}$ & 5.38 \\
$\mathrm{C}$ & $136.95 \mathrm{a}$ & $4.15 \mathrm{a}$ & 5.88 \\
$\mathrm{D}$ & $158.15 \mathrm{a}$ & $4.56 \mathrm{a}$ & 6.46 \\
$\mathrm{E}$ & $163.57 \mathrm{a}$ & $4.25 \mathrm{a}$ & 6.02 \\
$\mathrm{~F}$ & $147.59 \mathrm{a}$ & $4.04 \mathrm{a}$ & 5.72 \\
$\mathrm{G}$ & $145.81 \mathrm{a}$ & $4.13 \mathrm{a}$ & 5.85 \\
$\mathrm{H}$ & $164.56 \mathrm{a}$ & $4.36 \mathrm{a}$ & 6.17 \\
I & $151.85 \mathrm{a}$ & $4.22 \mathrm{a}$ & 5.97 \\
\hline \hline
\end{tabular}

Keterangan : Nilai rata-rata yang diikuti huruf yang sama pada kolom yang sama tidak berbeda nyata menurut uji jarak duncan pada taraf 5\%

Menurut Subekti dkk. (2007), pada masa vegetatif akhir tanaman menyerap unsur hara $\mathrm{P}$ sekitar 50\% lalu diikuti oleh $\mathrm{N}$ dan $\mathrm{K}$ masingmasing sebesar $60 \%$ sampai $70 \%$ dan $80 \%$ sampai $90 \%$. Maka untuk sampai panen kemungkinan tempat hidup mikroba sudah tidak lagi mendukung karena unsur-unsur hara makro yang sebagai nutrisi untuk menunjang hidupnya sudah tidak lagi mensuplai pertumbuhan mikroba untuk biosintesis sel (Ma'shum dkk. 2003).Pada masa vegetatif, unsur-unsur hara makro telah dipergunakan sehingga pertumbuhan mikroba kurang optimal dengan bertambahnya waktu mendekati panen.

Hasil pipilan kering yang rendah ini juga bisa berkaitan karena tidak sesuainya jarak tanam yang digunakan dalam percobaan dengan anjuran jarak tanam optimal. Secara umum, kepadatan tanam anjuran adalah 66.667 tanaman/ha. Ini dapat dicapai dengan jarak tanam $75 \mathrm{~cm} \times 20 \mathrm{~cm}$ dengan satu tanaman per lubang, atau jarak tanam $75 \mathrm{~cm} \times 40 \mathrm{~cm}$ dengan dua tanaman per lubang (Akil dan Hadijah, 2007).

Indeks Panen. Indeks panen adalah rasio hasil bobot kering biji dengan hasil bobot kering total tanaman. Nilai indeks panen optimal dapat bervariasi dari 0,15 sampai 0,52 dan nilai indeks panen dapat dipengaruhi oleh lama dan laju pertumbuhan (Goldsworthy dan Fisher, 1992). Indeks panen menggambarkan hasil asimiliat yang diperoleh tanaman (Gardner and Pearce, 1991).
Tabel 7. Pengaruh Jenis Pupuk Fosfat dan Waktu Aplikasi Pupuk Hayati Mikroba Pelarut Fosfat terhadap Indeks Panen

\begin{tabular}{cc}
\hline \hline Perlakuan & Indeks Panen \\
\hline A & $0.29 \mathrm{a}$ \\
B & $0.26 \mathrm{a}$ \\
C & $0.27 \mathrm{a}$ \\
D & $0.35 \mathrm{a}$ \\
E & $0.36 \mathrm{a}$ \\
F & $0.32 \mathrm{a}$ \\
G & $0.31 \mathrm{a}$ \\
H & $0.34 \mathrm{a}$ \\
I & $0.30 \mathrm{a}$ \\
\hline \hline
\end{tabular}

$\overline{\text { Keterangan : Nilai rata-rata yang diikuti huruf yang }}$ sama pada kolom yang sama tidak berbeda nyata menurut uji jarak berganda Duncan pada taraf $5 \%$.

Menurut Suhendar (2011) berdasarkan hasil penelitian Balai Penelitian Tanaman Pangan Bogor, nilai indeks panen untuk tanaman jagung pada daerah tropis sekitar 0.39. Nilai indeks dapat ditentukan oleh total hasil pipilan kering, bobot 100 biji dan indeks luas daun. Hasil penelitian pada semua perlakuan menunjukkan hasil yang tidak berbeda nyata dan dibawah kisaran indeks panen untuk tanaman jagung pada daerah tropis (Tabel 7).

Hal tersebut dapat disebabkan oleh bobot 100 biji yang rendah sehingga mempengaruhi rasio bobot biji dan total bobot kering tanaman. Meski demikian, nilai indeks panen perlakuan D dinilai cenderung lebih efisien dibandingkan perlakuan lain. Ini didasarkan pada nilai indeks panen pengaplikasian pupuk SP-36 dengan dosis $50 \%$ yang dikombinasikan dengan pupuk hayati MPF sebanyak 1 kali tidak berbeda jauh dengan nilai indeks panen yang didapat oleh perlakuan E, yang mengaplikasikan pupuk hayati sebanyak 2 kali dengan jenis dan dosis pupuk $\mathrm{P}$ yang sama dengan perlakuan $\mathrm{D}$.

\section{Kesimpulan}

Berdasarkan hasil dan pembahasan, maka kesimpulan pada percobaan ini adalah :

1. Jenis pupuk fosfat dan waktu pengaplikasian pupuk hayati mikroba pelarut fosfat hanya memberikan pengaruh terhadap panjang tongkol. Jenis pupuk fosfat dan waktu pengaplikasian pupuk hayati mikroba pelarut fosfat tidak memberikan pengaruh terhadap tinggi tanaman, indeks luas daun, diameter tongkol, jumlah baris biji per tongkol, 
jumlah biji per tongkol, bobot 100 biji, bobot biji pipilan kering per tanaman, bobot biji pipilan kering per hektar dan indeks panen pada semua perlakuan.

2. Perlakuan jenis pupuk SP-36 denga dosis $50 \%$ dari anjuran dengan pengaplikasian pupuk hayati MPF sebanyak 1 kali pada saat tanam cenderung lebih baik dan lebih efisien terhadap hasil tanaman jagung dibandingkan dengan perlakuan lain.

\section{Daftar Pustaka}

Akil, M. dan A.D. Hadijah. 2007. Budidaya Jagung dan Diseminasi Teknologi. Balai Penelitian Tanaman Serealia Maros. Departemen Pertanian.

Buckman, H.O. and N.C. Brady. 1969. The Nature and Properties of Soil. The Macmillan Company. New York. Diterjemahkan oleh Soegiman. 1982. Ilmu Tanah. Bhratara Karya Aksara. Jakarta

Budiman, A. 2004. Aplikasi Kascing dan Cendawan Mikoriza Arbuskula (CMA) pada Ultisol serta Efeknya Terhadap Perkembangan Mikroorganisme Tanah dan Hasil Tanaman Jagung Semi (Zea Mays L.). Skripsi Fakultas Pertanian Universitas Andalas, Padang. Tidak dipublikasikan

Fitriatin, B.N., A. Yuniarti., dan T. Turmuktini. 2013. Pegaruh Mikroba Pelarut Fosfat Penghasil Zat Pengatur Tumbuh terhadap Fosfat Tanah, Pertumbuhan dan Hasil Jagung serta Efisiensi Pupuk P pada Tanah Marginal. Laporan Penelitian. Jurusan Ilmu Tanah Fakultas Pertanian Universitas Padjadjaran. Jatinangor, Sumedang.

Gardner, F.P. and B. Pearce. 1991. Fisiologi Tanaman Budidaya (terjemahan dari Physiology of Crop Plants oleh Herawati Susilo). Universitas Indonesia (UI-Press). Jakarta

Goldsworthy, P.R. and N.M. Fisher. 1996. Fisiologi Tanaman Budidaya Tropik, Cetakan Kedua. Diterjemahkan oleh Tohari dari The Physiology of Tropical Field Crops (1984). Gadjah Mada University Press. Yogyakarta.

Hardjowigeno, S. 2007. Ilmu Tanah. Akademika Pressindo. Jakarta.

Hasanudin, dan G.M. Bambang.2004. Pemanfaatan Mikrobia Pelarut Fosfat dan Mikoriza untuk Perbaikan Fosfor Tersedia,
Serapan Fosfor Tanah (Ultisol) dan Hasil Jagung (Pada Ultisol). Fakultas Pertanian Universitas Bengkulu. Jurnal Ilmu-Ilmu Pertanian Indonesia. Vol. 6. No. 1. Hal 8 13. ISSN 1411 - 0067

Husen E. 2009. Telaah Efektivitas Pupuk Hayati Komersial dalam Meningkatkan Pertumbuhan Tanaman. Balai Penelitian Tanah. Bogor. Hal 105-117.

Isrun. 2006. Pengaruh Dosis Pupuk P dan Jenis Pupuk Kandang Terhadap Beberapa Sifat Kimia Tanah, Serapan P dan hasil Jagung Manis (Zea mays var Saccharata sturt) Pada Inceptisols Jatinangor. J. Agrisains Vol, 7 No.1:9-17.

Kusnadi, M.H. 2000. Kamus Istilah Pertanian. Penerbit : Kanisius. Yogyakarta.

Laiya, R., M.I. Bahua, dan Nurmi. 2013. Pertumbuhan dan Produksi Jagung Hibrida melalui Pemberian Pupuk Hayati. Laporan Penelitian. Jurusan Agroteknologi Fakultas Ilmu-Ilmu Pertanian Universitas Negeri Gorontalo. Gorontalo.

Maa'shum, M., J. Soedarsono, dan L.E. Susiolowati. 2003. Biologi Tanah. CPIU Pasca IAEUP Bagpro Peningkatan Sumberdaya Manusia Direktorat Jendral Pendidikan Tinggi Departemen Pendidikan Nasional. Jakarta.

Rahni, N.M. 2012. Efek Fitohormon PGPR Terhadap Pertumbuhan Tanaman Jagung (Zea mays). Jurnal Agribisnis dan Pengembangan Wilayah Vol.3 No. 2 Juni 2012. 2735p.

Sholeha, M. 2011. Respons Tanaman Jagung terhadap Perlakuan Dosis Batuan Fosfat Deposit Ciamis, Cileungsi, Tuban dan Pamekasan pada Oxisol. Jurusan Tanah Fakultas Pertanian Univ. Jember. Jember.

Subagyo, H., N. Suharta., dan A.B. Siswanto. 2004. Tanah-tanah Pertanian di Indonesia. Halaman 21-26. Dalam Prasetyo, B.H., Suriadikarta, D.A. 2006. Pengelolaan Tanah Ultisol untuk Pengembangan Pertanian Lahan Kering di Indonesia. Balai Penelitian Tanah. Bogor.

Subekti, N.A., dkk. 2007. Morfologi Tanaman dan Fase Pertumbuhan Jagung dalam Jagung: Teknik Produksi dan Pengembangan. Balai Penelitian Tanaman Serealia. Maros.

Suhendar, D. 2011. Pengaruh Dosis Pupuk N,P,K dan Jenis Pupuk Organik terhadap Pertumbuhan dan Hasil Tanaman Jagung (Zea mays L.) Hibrida P-12 di Jatinangor. Sumedang. 
Suriadikarta, D.A., R.D.M. Simanungkalit. 2006. Pupuk Organik dan Pupuk Hayati. Balai Besar Litbang Sumberdaya Lahan Pertanian. Badan Penelitian dan Pengembangan Pertanian. Bogor. ISBN 978-9799474-57-5

Sutopo. 2003. Kajian Penggunaan Bahan Organik Berbagai Bentuk Sekam Padi dan Dosis Pupuk Fosfat Terhadap Pertumbuhan dan Hasil Tanaman Jagung (Zea mays L.). Fakultas Pertanian UNS. Jurnal Sains Tanah Vol.. 3. No. 1. Hal 45. ISSN 1412-3606. Semarang
Tan, K.H. 2008. Soils in the Humid Tropics and Monsoon Region of Indonesia. CRC Press. Taylor and Francis Group. Boca Raton London New York.

Viruel, E., L. E. Erazzu. L. M. Calsina, M. A. Ferrero, M. E. Lucca, and F. Sineriz. 2014. Inoculation of Maize with Phosphate Solubilizing Bacteria: Effect on Plant Growth and Yield. Journal of Soil Science and Plant Nutrition, 14 (4). 819 - 831. Tucuman.

Winarso. 2005. Pengertian dan Sifat Kimia Tanah. Yogyakarta. Gajah Mada University Press. Yogyakarta 